\title{
The Joke Is on You: Humor, Resistance through Culture, and Paradoxical Forms of Dissent in Communist Romania
}

The Joke Is on You: Humor, Resistance through Culture, and Paradoxical Forms of Dissent in Communist Romania. The author of the article focuses on showing that resistance through culture is part of a social and political dynamic that is complicated and paradoxical. He claims that a discursive analysis of power relationships and of the rapport between the private and official idioms in the political context of communist totalitarian societies can evince the daunting complexity of some forms of resistance-through-culture discourse. The author argues that with the appropriate critical instruments, cultural discourse analysis can broach the intricacies and paradoxes of power relationships in oppressive environments and can ground a more accurate and unprejudiced moral evaluation of resistance through culture as a phenomenon typical of totalitarian cultural politics.

Keywords: resistance, culture, communist Romania, humor

After the fall of the communist dictatorship, Romanian intellectuals were confronted with the specter of their own behavior during totalitarianism. A fierce debate ensued which split the intellectual community in two irreconcilable, resentful camps. Some have accused cultural elites for not openly opposing the regime and for their lack of solidarity with the occasional workers' protests (the miners in 1977, the workers in Brașov in 1987) or even with the individual acts of dissidence from their peers.

* Address: Facultatea de Limbi şi Literaturi Străine, Str. Edgar Quinet 5-7 Sector 1, 70106, Bucharest, Romania. E-mail: stefbogdan@gmail.com. 
Indeed, scattered voices like the writers Paul Goma (a supporter of the Charter '77 movement) and Mircea Dinescu, academics like Doina Cornea, or scientists like Gabriel Andreescu were openly critical of the regime but found no support among their fellow intellectuals. The other camp, however, has been claiming that, in fact, such elites were practicing an unspectacular opposition, the so-called "resistance through culture". This curious concept amounts to what Andrei Pleșu dubbed with an obvious paraphrase "the banality of good", something that he describes in terms of:

... having survived decently, having preserved your honorability, not having "sullied" yourself... a belligerence of the thing well done, of the profession kept uncontaminated by extra-professional criteria and exigencies, especially in those fields that are directly vulnerable to the ideological imperative. To refuse to write odes and poetic tributes, to resist party taboos, to keep your writing and your thought from servicing the official propaganda, to decline "commissions" from activists and negotiations with the censors - all of these are more than the simple forms of a hygienic defeatism, of a minor and politically "insufficient" gesticulation. To stubbornly protect your inner freedom and your verticality, to market only "products" whose value is in themselves, not in their aesthetic and philosophical servility is, after all, to "resist". Not without risks. ... We can even pursue this line of argument to the level of "dainty ideas", of diaphanous "trifles". Elegance in dress and conduct, a good use of language, politeness, humor, concern for educating the young, and, generally, for cultural life - in a world of ill-manners, arbitrariness, and a domineering lack of culture, all of these counted as forms of "resistance"1.

Pleșu is, in fact, describing what I would call a "samizdat of style", that is, displaying and propagating, usually inside the close circle of your friends and acquaintances, of a personal life-style, a set of manners and values that was or could be condemned by the official discourse and ideology as (petty) bourgeois or aristocratic.

What sits badly with my understanding in this debate is, mostly, the tendency of the two camps to exaggerate and oversimplify - after all, a not uncommon rhetorical move in a polemic. In such radical accounts, resistance through culture becomes for its accusers a despicable form of cowardliness and collaboration when compared to the 1956 anti-communist revolt in Hungary, the Charter' 77 or Solidarity. Conversely, the supporters of this indirect form of endurance claim that people whose professions were to think and write, resisted the proud impulse to reject any

1 ... ai supravieţuit cuviincios, că ţi-ai păstrat onorabilitatea, că nu te-ai "murdărit"... o dimensiune ofensivă a lucrului bine făcut, a meseriei care nu se lasă contaminată de criterii și exigenţe extra-profesionale. Așa se întîmplă mai ales în domeniile direct vulnerabile faţă de imperativul ideologic. A refuza să faci poezie omagială, a nu ceda tabuurilor de partid, a nu te angaja prin scrisul și ideile tale în serviciul propagandei oficiale, a refuza "comanda" activiștilor și negocierile cu cenzura, toate astea sint mai mult decît simple forme de defetism salubru, de gesticulaţie minoră, "insuficientă" politic. A-ţi proteja, cu încăpăţînare, libertatea interioară și verticalitatea, a nu pune pe piaţă decît "produse" valide prin ele însele și nu prin servilism estetic sau filozofic înseamnă, pînă la urmă, "a rezista”. Nu fără riscuri... Mai mult: avem dreptul să mergem, pe linia aceasta, pînă în registrul "ideilor gingașe", al "mărunţișurilor" diafane. Eleganţa vestimentară și comportamentală, buna folosirii a limbii, politețea, umorul, grija pentru educaţia tinerilor, viaţa culturală în genere au putut fi, într-o lume a grosolăniei, arbitrarului și inculturii suverane, forme de "rezistență". A. Pleșu, "Rezistența prin cultură" (Resistance through Culture), Dilema veche 348, 14-20 Oct. 2010, http://dilemaveche.ro/sectiune/situatiunea/arti$\mathrm{col} /$ rezistenta-cultura (access: 10.10.2016). Unless otherwise indicated, all translations are mine. 
compromise with the communist system and thus forsake their call. Instead, they allegedly found a much wiser and more efficient solution: to never give up on one's profession and to resist the regime through a non-propagandistic, an ideologically non-aligned culture which in the end has ensured the survival and wholesomeness of intellectual vocations and has provided a living example of how you could practice them in a decent way, untainted by communist dogma. The Păltiniş school, around philosopher Constantin Noica, was probably the most popular and widely respected movement of such indirect dissent. Noica found resistance through culture to be philosophically superior to civic and political commitment. On the other hand, Alexandra Laignel-Lavastine (on Noica 1998) and Dorin Tudoran (in Timpul $1 / 2012 \mathrm{pag} / 3$ ) have undermined such claims by unfavorably comparing Noica and his Kantian-Spenglerian understanding of culture with Ian Patocka's attitude and with the latter's central role in the Charter ' 77 movement $^{2}$.

Either way, the two positions on the question of resistance through culture have been commonly deemed irreconcilable, mutually exclusive and, what is more to the point for this essay, resistance through culture was seen, depending on your ideological alliance, as either entirely immoral, or entirely noble and superior. Resistance through culture is part of a social and political dynamic that is far more complicated and paradoxical than either of its one-dimensional portrayals in this debate. I am proposing that a discursive analysis of power relationships and of the rapport between the private and official idioms in the political context of communist totalitarian societies can evince the daunting complexity of some forms of resistance-through-culture discourse. With the appropriate critical instruments, which I am providing in this essay, I believe cultural discourse analysis can broach the intricacies and paradoxes of power relationships in oppressive environments and can ground a more accurate and unprejudiced moral evaluation of resistance through culture as a phenomenon typical of totalitarian cultural politics.

The question of resistance to oppression has famously been theorized by political anthropologist James C. Scott in his studies of subordinate groups in oppressive social or political environments. Scott's model relies on the distinction between two types of behavior which are indicated by the divergent public and private discourse, respectively (the latter of which he dubs the "hidden transcript") ${ }^{3}$. He dwells on the ambivalence and duplicity of subaltern social performance as he describes everyday resistance as the secret critique of authority that goes on off-stage, contrary to public interaction which abides by the rules of the dominating agency. Scott suggests that resistance is carried out in spontaneous and surreptitious private forms, a non-programmatic anarchist kind of dissent.

2 A. Laignel-Lavastine, Filozofie și naționalism. Paradoxul Noica, București 1998, pp. 295-314.

3 J. C. Scott, Domination and the Arts of Resistance: Hidden Transcripts, New Haven and London 1990; J. C. Scott, Weapons of the Weak: Everyday Forms of Peasant Resistance, New Haven and London 1985. 
Scott claims, especially in Domination and the Arts of Resistance, that his model regarding stealthy, unassuming resistance through "hidden transcripts" has universal applicability. One feels encouraged, then, to also employ it in the context of communist Romania (and of Eastern Europe, generally). Let me invoke two examples of resistance of communist dictatorship. The first is that of political jokes (e.g. "under capitalism man exploits man, under communism it's just the other way round" cf. John Kenneth Galbraith quoting a Polish joke), which were normally operating under the radar in the form of "private/hidden transcripts" to use Scott's terms, or, in lay terms, of humor directed against the authorities in private discourse and contexts. The second is innuendo in the arts, or what the Romanians called "lizards" (Romanian șopirle, pronounced/Jopirle/). These were disguised references to, and criticism of, the authorities in public speech. They were called "lizards" because, like these reptiles, they were undetectable, furtive, quick(-witted) and they seem to provide a perfect example of what Scott described as "the manifold strategies by which subordinate groups manage to insinuate their resistance, in disguised forms, into the public transcript". Scott believes that "most of the political life of subordinate groups is to be found neither in overt collective defiance of powerholders nor in complete hegemonic compliance, but in the vast territory between these two polar opposites"4.

In Romanian culture, "lizards" could take many forms. One highly esteemed type were the dim, elusive allegories, such as those seen in the films of directors Dan Pița and Mircea Danieliuc, whose dystopias pointed at now concrete historical context, but recreated a totalitarian atmosphere in poetic, suggestive fashion. "Lizards" also came under the guise of historical fiction that looked like it was aimed at past regimes, but actually described them in terms that clearly applied to the communist present. (Additionally, in the late 1960s and early 1970s more liberal artistic references to the excesses and mistakes of the Stalinist stage in Romanian communism were tolerated by the censorship, in order to indirectly show by comparison, how much better communism had become under Ceaușescu's liberal, anti-Soviet rule.) One extremely popular short novel was Silviu Angelescu's Calpuzanii (The Counterfeiters) which describes the 18th-century corrupt and repressive court of an absolutist and madly impulsive prince, and ends with the apotheotic feat of a disgruntled dissenter who dumps a massive amount of yeast in the princely privy chambers, which eventually rises and inundates the palace. This was a thinly disguised hint at contemporary Romanian society which was, so to speak, full of it, and could only end by drowning in its own ordure ${ }^{5}$.

${ }^{4}$ J. C. Scott, Domination and the Arts of Resistance, p. 136.

5 Other kinds of allusive discourse in the arts (especially literature and dramatic arts) included Ana Blandiana's apparently innocuous children's books whose protagonist is a spoiled and insensitive, egomaniacal tom-cat, Arpagic (Chives) or incidental stabs at mad dictators as in Silviu Purcăretețs production of Hamlet at the Bulandra Theatre in Bucharest, where spectators could hardly wait to cheer at Claudius's line "Madness in great ones must not unwatch'd go." 
So far, Scott's depiction of dissenting discursive maneuvers to covertly oppose and undermine the regime of an oppressive authority seems to work just fine. But one cannot ignore a more sophisticated, deconstructive reading of the discourse of the weak and the strong alike, which may indicate the limits of Scott's model. Indeed, what makes communist oppression so dangerous and devastating to human nature is that it secretly infects the free subject while at the same time inculcating the illusion that dissent is possible. In the former communist Europe, this social disease contaminated both the open dissenters and the less heroic survivors, the latter category including the everyday resistance of the many alongside the intellectual elite's resistance through culture.

As mentioned above, everyday resistance often took the form of political jokes. But such jokes could work both ways and they hid an unpleasant truth. They generated a split in one and the same individual subject, a duplicitous coexistence in one and the same consciousness of both conformist public and dissenting private attitudes, of both the official and the confidential discourse. The paradoxical conflation of the point of view of the oppressive authorities and of the dissenter was not just a form of liberation, it was equally a form of debasement and of the assimilation or banalization of evil. Perhaps one Romanian joke (if one can, in fact, establish the origin of such widely circulated anecdotes in the region) best illustrates this strange duality of consciousness under communism:

A Western journalist visits Romania to report on life under communism. The authorities carefully orchestrate his sampling of everyday Romanian life, but at one point he wants to talk to random people in the street. He stops one man and starts to question him about the economy, agriculture and industry, cultural life etc. Cautiously, aware of secret police surveillance, the interviewee only responds by quoting from the official doctrine. The reporter stops him and asks: "But don't you have your own opinion about such things?" To which the man replies falteringly "Sure I do..., then adds in a firm voice “... but I strongly disagree with it!".

Disagreeing with your own opinion may sound harmlessly silly, but it is the dramatic evidence of a schizoid coexistence of sincerity and hypocrisy in the psyche of communist subjects. The Hungarian counterpart of this joke shows just how damaging this personality disorder was not only to oneself, but also to your fellow human beings.

A judge splits his sides with laughter. "Why are you laughing?" a colleague asks. "I've just heard this fabulous joke!" "Let's hear it, then!" "No way. I just sentenced a guy to three years in prison for telling this joke"6.

Hungarian writer and editor András Jolsvai, who reports this joke, commends the social function of political jokes in a typical attitude towards the role of humor under oppression:

${ }^{6}$ A. Jolsvai, “Cum ne amuzam în comunism”, Reader's Digest Romania, 30 April 2012, http://www. erd.ro/cum-ne-amuzam-in-comunism- (access: 10.10.2016). 
Political jokes made you part of a community. In a dictatorship, no matter how light, everybody is on the same side. I heard a joke about Khrushchev from a Hungarian party secretary, a joke about the Warsaw Pact from an officer, a joke about snitches from a snitch.... We were glad to portray the Soviets as clowns, to jeer at the gulf between communist theory and practice, at our own leaders, and at the official critique of "imperialism"7.

In fact, an ugly truth lies behind the self-delusion of covert opposition: the jokers are drawn into an unwitting collaboration with the oppressor and into complicity to evil! When Jolsvai claims that "in a dictatorship, no matter how light, everybody is on the same side", he fails to acknowledge how that includes the dictators themselves: they too are on our side - and we on theirs. In the words of Romanian author and civic activist, Ionel Alexe:

Although the coded language of Romanians under communism displays the traits of a vehicle of freedom, this is simply an illusion. This language was not only tolerated, it was discretely encouraged by communist authorities. That is because "nea Nicu" [uncle Nick], Ceaușescu became "one of us", he stepped onto our porch as a benign fellow, with his own human joys and sorrows ${ }^{8}$.

David Crawford also thinks that beyond James C. Scott's notion that social (re) action can be "a subtle mixture of outward compliance and tentative resistance" lies the sobering truth that "[social] acts can simultaneously resist and comply". The obverse function of resistance has been acknowledged as early as Freud, who observed that "wit gives the unconscious and the censor a holiday. By bringing different, even conflicting ideas into juxtaposition with an economy and charm that reduces the threat in the conflict, a joke thereby reduces the efforts of the censor" ${ }^{10}$. Freud manages to transcend the commonplace critical imagination which is only sensitive to the mechanisms of one-way subversion (the weak undermining oppressive authority). Even Foucault's concept of counter-discourse follows this unidirectional logic, although at times he seems to point at the more interesting complications of counter-discourses in power relationships:

There is not, on the one side, a discourse of power, and opposite it, another discourse that runs counter to it. Discourses are tactical elements or blocks operating in the field of force relations; there can exist different and even contradictory discourses within the same strategy; they can, on the contrary, circulate without changing their form from one strategy to another, opposing strategy ${ }^{11}$.

${ }^{7}$ Ibid.

8 "Limbajul codat şi umorul în Epoca de Aur. Cum fentau românii comunismul prin umor. Cele mai savuroase bancuri cu cizmarul şi savanta”, Adevărul, 14 March 2013, http://adev.ro/mjns16 (access: 10.10.2016).

9 D. L. Crawford, “The Temporality of Resistance”, [in:] Beyond Resistance: The Future of Freedom, ed. R. Fletcher, New York 2007, p. 3.

${ }^{10}$ The Culture of Biomedicine: Studies in Science and Culture (Studies in Science \& Culture), ed. by D.H. Brock, A. Harward, Newark, London and Toronto, 1984, p. 174.

11 M. Foucault, The History of Sexuality. Vol. 1: An Introduction, New York 1978, p. 102. 
Elsewhere I have described the paradoxical complexities of what I would call "contra-discourse", a baffling form of para-resistance wherein the official discourse and its antagonist (counter-discourse) become ironically interfused ${ }^{12}$. The ambivalent coexistence of contrary discourses, of the language of power alongside the idioms of resistance or opposition to power is an interesting case of, so to say, covert dialogism. Ideological stands and strategic positionings are no longer discrete and the meaning and function of both discourse and counter-discourse are no longer univocal.

Humor under communism presents us with lots of examples of contradiscourse. One such instance is the way in which the authorities encouraged social satire of an abusive leadership through televised skits. This type of satire naturally came in a half-hearted and deflected form, and it was meant to cunningly defuse the explosive content and subversive function of counter-discourse and even of "lizards" themselves. At times such satirical acts were performed by artists who apparently kept clear of propagandistic art. Such was the case of Toma Caragiu, a widely loved and respected comedian whose reputation and art remained unblemished because he never recited commissioned poems dedicated to Ceaușescu or to the communist ideals (as many other actors used to do at the time). In 1969, however, Caragiu delivered on national television one of his hugely enjoyed satirical monologs, called "The Man with the Lizard". It is clear from the very title that the idiom of Partyauthorized satire now incorporated this encoded slang key-term of the counterdiscourse. Moreover, through its content, the skit also altered the popular meaning of the term, that of covertly resisting oppression through oblique, disguised allusions. In that comedic routine, a "lizard" came to mean insidious and anonymous slander or backstabbing (a mock genealogy included Mazarin, the Borgias, and Shakespeare's Iago), as well as "healthy" criticism of all social mores that ran contrary to official communist ethics. There is even a deliberate tension between public and private discourse in Caragiu's manner of acting: at a textual level, he seemed to speak about immoral individuals who slander other people in order to ingratiate themselves with their bosses, but his conspiratorial tone and cautious side glances indicate at once the insecure, dangerous environment and the psychological terror caused by the secret police and the widespread practice of snitching ${ }^{13}$. So, on the one hand, Caragiu was winking at the public about the known everyday practices of resistance through "lizards" (Radio Free Europe was alluded to as Radio "Free Lizard"), on the other, he was instrumental in the officially sanctioned maneuver of counter-subverting the discourse of covert opposition to the regime ${ }^{14}$.

12 B. Ștefănescu, "Remembrance of Things Post. Revisiting the Trauma of Communism in Style", University of Bucharest Review 1, 2013, pp. 16-17.

13 The general belief at the time was that surveillance from the secret police was so pervasive that every third Romanian was an informer or an officer.

${ }^{14}$ In fact, Caragiu was also instrumental to these duplicitous tactics when he accepted a part in a series of populist-nationalist film productions about 18th- and 19th-century haiduci (Romanian 
The official institutions of discourse control (national television, state-owned publishing houses and journals etc.) were actively taking counter-measures against ideological resistance by assimilating and defusing dissenting idioms, and by occasionally easing censorship and even showing tolerance toward political jokes. Caragiu's skit was one of many such acts of establishing a template for contradiscourse by ironically overturning and assimilating the instruments of counterdiscourse. It may look like the establishment were striking back, but this was consistently a double-edged sword, no matter who handled it. The regime, on the one hand, appropriated and internalized subversive discursive mechanisms such as irony and double-codedness but it also owned up to its imperfections. On the other hand, the resisting individuals felt more at ease when using oppositional discourse while at the same time they internalized censorship and fragments of the official idiom in a collaborative act. Popular thought became infused with the populist values of late Romanian communism - uncritical nationalism, equalitarianism, the alleged superiority of the lower classes and of folklore etc.

One has to conclude from such examples that the contra-discourse of everyday resistance against communism inadvertently contributed, in the words of Polish cultural critic Hanna Gosk, to "the real power of imperial discourse which, thanks to the long-standing symbiotic coexistence with counter-discourse, becomes 'tamed' and establishes a modus vivendi with its contestatory partner"15.

outlaws of the Robin Hood type) for which the screenwriter was one of the most despicable of collaborationist writers, Eugen Barbu (whose wife was the lead actress in these films). In conceding to take part in such productions, Caragiu, who played a facetious defrocked priest, indirectly attracted popular sympathy towards the official atheist discourse of national-communism.

15 H. Gosk, "Counter-discourse and the Postcolonial Perspective: The Polish Complex by Tadeusz Konwicki”, Journal of Postcolonial Writing 48, 2012, no. 2, p. 202. 